\title{
Importance of market-oriented research for rice production in Tanzania. A review
}

\author{
Nobuhito Sekiya ${ }^{1}$ (D) Nobuaki Oizumi ${ }^{2}$ - Theodore T. Kessy ${ }^{3} \cdot$ Kitilu M. J. Fimbo $^{3}$ - Motonori Tomitaka ${ }^{2}$. \\ Keisuke Katsura ${ }^{4} \cdot$ Hideki Araki $^{5}$
}

Accepted: 30 January 2020 / Published online: 18 February 2020

(C) INRAE and Springer-Verlag France SAS, part of Springer Nature 2020

\begin{abstract}
Rice consumption in Tanzania has greatly increased since the 1960s; it is predicted to continue to increase owing to urbanization and changes in consumer preferences from traditional staples to rice. In this study, we review rice agroecology, its value chain, and price determinants, and the history of and challenges to rice research in Tanzania. Our main findings are as follows: (1) rice cultivation can be classified into three major categories: irrigated lowland, rainfed lowland, and rainfed upland. Irrigated lowland is then subdivided into the permanent river, seasonal water, dam, and groundwater subtypes, while rainfed lowland is subdivided into flood plain (fields near rivers), catchment (fields on gentle slope in catchment basin), narrow valley (fields on flat narrow valley bottoms), and plain grassland (fields on gentle slope in savannah grassland). (2) Various stakeholders are involved in production, storage, milling, wholesale, retail, and trade at local, urban, regional, and national levels, resulting in higher market prices of local rice compared to imported rice. However, consumers still choose local rice consisting of traditional cultivar because of its distinct taste and aroma. (3) Improving yield potential through the introduction of foreign elite lines/cultivars has been a major research target; however, farmers have been rejecting most of the new cultivars due to poor grain quality. (4) An integrated set of agronomic management techniques is effective in increasing the yield of traditional cultivars under irrigated lowland. Technical package effectiveness has yet to be tested in all subtypes of rainfed lowland. We propose a new research framework for rice production in Tanzania that is greatly oriented toward meeting consumer demands. In the framework, both breeding and agronomy should have specific research targets for each agroecosystem. Furthermore, genetic resources of traditional cultivars should be fully explored. This study shows the importance of multidisciplinary approach in improving rice production in Tanzania.
\end{abstract}

Keywords Agroecology $\cdot$ Breeding $\cdot$ Consumer preference $\cdot$ Local cultivars $\cdot$ Rice $\cdot$ Value chain

Nobuhito Sekiya

kapinivilage@yahoo.co.jp

1 Graduate School of Bioresources, Mie University, Tsu, Mie 514-8507, Japan

2 Japan International Cooperation Agency (JICA) Tanzania Office, P.O. Box 9450, Dar es Salaam, Tanzania

3 Tanzania Agricultural Research Institute (TARI), Private Bag, Ifakara, Morogoro, Tanzania

4 Graduate School of Agriculture, Tokyo University of Agriculture and Technology, 3-5-8, Saiwaicho, Fuchu, Tokyo 183-8509, Japan

5 Graduate School of Science and Technology for Innovation, Yamaguchi University, 1677-1 Yoshida, Yamaguchi 753-8515, Japan

\section{Contents}

1. Introduction

1.1 Overview of rice production

1.2 History of rice production

2. Rice agroecology

2.1 Geographical distribution of rice agroecology

2.2 Classification of rice agroecology

2.2.1 Irrigated lowland rice

2.2.2 Rainfed lowland rice

2.2.3 Rainfed upland rice

3. Rice market

3.1 Rice value chain

3.2 Rice prices

4. Rice research

4.1 History of rice research 
4.2 Traditional rice cultivars

4.3 Challenges in rice breeding

4.4 Challenges in rice agronomy

4.5 A way forward

5. Conclusion

Acknowledgments

References

\section{Introduction}

\subsection{Overview of rice production}

Rice consumption in Tanzania greatly increased from 94,000 MT of milled rice in the 1960 s to $1,800,000 \mathrm{MT}$ in the 2010s (USDA (United States of America Department of Agriculture), 2019). Tanzania's domestic supply of milled rice totaled approximately 1,200,000 MT in 2013, making it the seventh largest rice producer among African countries (FAO 2019). Tanzania's population has been expanding continuously since the 1950s (FAO 2019), with its rural population migrating to major cities such as Dar es Salaam and Arusha in the 1970s. As a result, a large consumer population has grown in urban areas. Because consumers in urban areas tend to change their food preferences from traditional staples such as maize and tubers to rice (Nkonya and Barreiro-Hurle 2012; Lazaro et al. 2017; Wilson and Lewis 2015) (see Fig. 1), the domestic supply of milled rice has been sharply increasing since the $1980 \mathrm{~s}$ (USDA (United States of America Department of Agriculture), 2019). Consequently, per capita consumption - estimated by dividing domestic consumption (USDA (United States of America Department of Agriculture), 2019) by the total population (FAO 2019) - has also been sharply increasing since the 1990s. The nation's urbanization and change in consumer preferences are expected to continue, and rice consumption is thus predicted to increase in the near future (MAFC 2009).

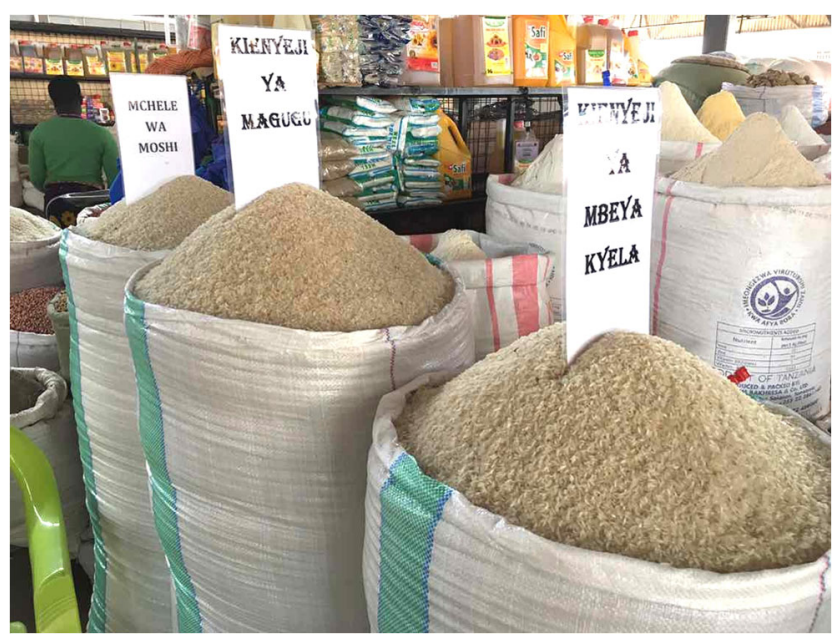

Fig. 1 Tanzanian rice market
In response to the increasing rice demand, Tanzanian rice production increased between the 1960s and 2010s (FAO 2019). This increase was attained mainly through an expansion of the cultivated area rather than yield improvement. While the rice cultivated area increased ninefold from 100,000 ha in the 1960s to 960,000 ha in the last decade (2007 to 2016), the mean rice yield increased only 1.8 times, from 1.2 to $2.2 \mathrm{t} \mathrm{ha}^{-1}$. This small increment in rice yield contrasts with the large increase from 2.1 to $4.8 \mathrm{t} \mathrm{ha}^{-1}$ in the East, South, and Southeast Asian countries during the same period.

Tanzania has a long history of rice cultivation. Rice is grown in various environments, ranging from semi-arid regions with less than $800 \mathrm{~mm}$ of rainfall (Meertens et al. 1999) to humid regions with more than $1500 \mathrm{~mm}$ (Sekiya et al. 2013), as well as from lowland areas (Kadigi et al. 2004) to steep slopes (Sekiya et al. 2015). Indica rice cultivars, thought to have been brought to Tanzania by sea traders (Carpenter 1978; Lu and Chang 1980), have adapted to the country's environments, resulting in the development of a great number of local cultivars (Mogga et al. 2018; Satoh et al. 1990; Suvi et al. 2019). A combination of diverse environments and rich genetic resources has enabled the development of unique rice agroecosystems throughout the country (Kadigi et al. 2004; Kafiriti et al. 2003a; Meertens et al. 1999; Rodenburg 2013; Sekiya et al. 2015). Rice markets have developed in many regions (Kato 2007) in recent years, attracting many small-scale farmers to rice cultivation (Kadigi et al. 2004; Kato 2007; Meertens et al. 1999). The unique agroecosystems and increasingly complicated rice markets present great challenges to rice researchers aiming to increase the nation's rice production. Therefore, this study reviews previously published literatures relevant to rice agroecology, its rice value chain, and price determinants, and the history of and challenges to rice research in Tanzania. On the basis of findings, a new research framework that is greatly oriented toward meeting consumer demands is proposed for rice production in Tanzania.

\subsection{History of rice production}

Oryza sativa is thought to have been introduced by sea traders 2000 years ago to locations in the coastal region of Tanzania such as Zanzibar and Kilwa (Carpenter 1978; Lu and Chang 1980). During the Islamization of Pemba island in Zanzibar from the eighth to fifteenth centuries, irrigated rice cultivation was brought to the island (Walshaw 2010). By the early nineteenth century, irrigated rice was already being grown in small-scale fields in the Kilombero valley, the Morogoro region (Kato 2007), and the Usangu basin in the Mbeya region (Kadigi et al. 2004) on the mainland. In the mid-nineteenth century, Arabic slave traders cultivated rice plants around their trade bases in inland regions, allowing rice plants to penetrate into the northern part of Tanzania (Meertens et al. 1999). 
Indica rice cultivars were grown as a cash crop in northern Tanzania during the 1930s (Meertens et al. 1999).

The first modern irrigation system for rice production (1000 ha) was introduced by the colonial government at Kilangali, Morogoro, in 1948; the scheme was abandoned in 1951 (Therkildsen 2011). After the 1967 Arusha Declaration (policy on socialism and self-reliance), financial support for state-owned rice irrigation schemes was obtained from major donor countries, including China and North Korea (Therkildsen 2011). Dakawa (2000 ha), Ruvu (725 ha), Kapunga (3000 to 4000 ha), and Mbarali (3200 ha) are the major state-owned schemes. Overall, degraded management practices caused by financial constraints gradually reduced productivity and the cultivated area in the state-owned schemes. Beginning in 1986, Tanzanian market liberalization attracted a great number of private enterprises to the nation's rice industry (Kato 2007). As a result, rice markets grew across the country, encouraging small-scale farmers to expand Tanzania's rice cultivated area (Kadigi et al. 2004; Kato 2007; Meertens et al. 1999).

\section{Rice agroecology}

\subsection{Geographical distribution of rice agroecology}

Rice production is broadly distributed over Tanzania, as its environmental conditions have provided rice farmers with great opportunities to develop unique agroecosystems.

The Mwanza, Shinyanga, and Tabora regions in the northwest are occupied by savannah grasslands. In general, these three regions receive limited annual rainfall, of 500 to $800 \mathrm{~mm}$, and farmers grow rice plants in rainfed lowlands on gentle slopes using water-harvesting techniques (Meertens et al. 1999) that are described in detail in a later section of the review.

The Kilimanjaro region in the northeast achieves high rice yields in large-scale irrigation schemes constructed by national and international organizations (Ikegami, 1995; Ikegami, 2001; Yamada, 1999). Rice can be grown two to three times annually as long as water is available throughout the year (Ikegami, 1995; Sekiya et al. 2017).

The Morogoro region accommodates many irrigation schemes at various scales. Due to its relatively large annual rainfall, of 1000 to $2000 \mathrm{~mm}$ annually, rice yields are high even in rainfed fields (Kato 2007). Upland rice plants are also grown in mountainous terrain (Sekiya et al. 2015).

The Mbeya and Rukwa regions in the south also accommodate various sizes of irrigation schemes that introduce irrigation water from many rivers and streams (Kadigi et al. 2004). The abundant annual rainfall of 800 to $2800 \mathrm{~mm}$ allows relatively high rice yields in rainfed fields. Rice from the two regions is traded at high prices in the domestic market due to its high-quality taste and aroma (Sekiya et al. 2013; Senda 1999).

Coastal regions such as Tanga, Pwani, Lindi, Mtwara, and Zanzibar are also famous for their rice cultivation. Many small-scale rainfed fields are found in inland valleys, where rice plants are dependent primarily on runoff from downslopes (Kafiriti et al. 2003c; Sekiya et al., 2013, 2015).

\subsection{Classification of rice agroecology}

The Africa Rice Center (AfricaRice) classified Africa's ricegrowing environments into three major categories: "irrigated lowland," "rainfed lowland," and "rainfed upland" (Diagne et al. 2013). They further identified two additional agroecosystems in unclear transition zones: "intensified lowland" between irrigated and rainfed lowlands and "lowland fringe (hydromorphic)" between rainfed lowland and upland. Tanzania's rice agroecosystems fall under the three major categories (see Table 1). However, the classification into the two transition zones is challenging due to uniqueness of the rice agroecosystems in Tanzania. For a better understanding of the rice agroecosystem in Tanzania, this review further introduces subtypes in irrigated and rainfed lowlands based on the terrain and/or water source of each sub-category shown in Table 1. The AfricaRice classification that corresponds to each subtype is also indicated.

\subsubsection{Irrigated lowland rice}

Tanzania has approximately 3000 irrigation schemes totaling 270,000 ha, of which rice plants are grown in 461 schemes covering approximately 100,000 ha. Water is drawn from permanent rivers (Sekiya et al. 2017), seasonal waters (Manero et al. 2019), dams (Komakech et al. 2012), or ground waters (Mato 2002) (see Table 1). Irrigation schemes like the ones in the Kilimanjaro region grow rice plants twice or even three times a year by taking advantage of modern irrigation facilities as well as permanent water sources (Ikegami, 1995; Sekiya et al. 2017). In the case of the Lower Moshi Irrigation Scheme (LMIS), however, the high productivity of irrigated rice has led to the expansion of irrigated areas and the intensification of cultivation upstream, causing in turn water shortage in the scheme itself (de Bont 2018). In irrigation schemes that depend on seasonal waters, such as those in the Morogoro, Mbeya, and Rukwa regions, rice plants are often grown under rainfed conditions in years with limited rainfall (Manero et al. 2019). The basic cultivation techniques shown in Table 2 are used in almost all the schemes thanks to an extension service provided by the government; the only exception is newly developed irrigation schemes where the service has not yet been introduced (Sekiya et al. 2017). The high productivity of schemes like LMIS is partly due to the high adoption rate of 
Table 1 Rice agroecosystems in Tanzania

\begin{tabular}{|c|c|c|c|c|}
\hline $\begin{array}{l}\text { Major } \\
\text { agroecosystem }^{\text {a }}\end{array}$ & Agroecosystem subtype $^{\mathrm{b}}$ & Cropping & References & Agroecosystem in Africa $^{c}$ \\
\hline \multirow[t]{4}{*}{ Irrigated lowland } & Permanent rivers & $\begin{array}{l}\text { Rice plants are grown twice a } \\
\text { year in some irrigation schemes. }\end{array}$ & Sekiya et al. (2017) & Irrigated lowland \\
\hline & Seasonal waters & $\begin{array}{l}\text { Rice fields are converted to rainfed } \\
\text { cropping system when no water } \\
\text { is available. }\end{array}$ & Manero et al. (2019) & $\begin{array}{l}\text { Irrigated lowland-intensified } \\
\text { lowland }\end{array}$ \\
\hline & Dams & $\begin{array}{l}\text { Rice fields are converted to rainfed } \\
\text { cropping system when no water } \\
\text { is available. }\end{array}$ & Komakech et al. (2012) & $\begin{array}{l}\text { Irrigated lowland-intensified } \\
\text { lowland }\end{array}$ \\
\hline & Groundwater & Cropping depends on water pumps. & Mato (2002) & $\begin{array}{l}\text { Irrigated lowland-intensified } \\
\text { lowland }\end{array}$ \\
\hline \multirow[t]{4}{*}{ Rainfed lowland } & Flood plain & $\begin{array}{l}\text { Fields are constructed near rivers to } \\
\text { use river floods effectively. Water } \\
\text { stays for a few days to weeks. }\end{array}$ & $\begin{array}{l}\text { Kadigi et al. (2004), } \\
\text { Kangalawe and } \\
\text { Liwenga (2005) }\end{array}$ & Rainfed lowland \\
\hline & $\begin{array}{l}\text { Gentle slope in catchment } \\
\text { basin (catchment type) }\end{array}$ & $\begin{array}{l}\text { Fields are constructed on gentle } \\
\text { slope in catchment basin of rivers. } \\
\text { Runoff is collected when rainfall } \\
\text { is adequate, and fields are flooded } \\
\text { when rainfall is excessive. }\end{array}$ & Kato (2007) & $\begin{array}{l}\text { Rainfed lowland-lowland } \\
\text { fringe }\end{array}$ \\
\hline & $\begin{array}{l}\text { Flat narrow valley with } \\
\text { moderately steep side } \\
\text { slopes (narrow valley type) }\end{array}$ & $\begin{array}{l}\text { Fields are constructed on flat narrow } \\
\text { valley bottoms in inland valleys } \\
\text { with moderately steep convex } \\
\text { side slopes. Water gathers down } \\
\text { slopes surrounding rice fields. }\end{array}$ & Rodenburg (2013) & Lowland fringe \\
\hline & $\begin{array}{l}\text { Gentle slope in savannah } \\
\text { grassland } \\
\text { (plain grassland type) }\end{array}$ & $\begin{array}{l}\text { Fields are constructed on gentle } \\
\text { slope in savannah grassland. } \\
\text { Water is harvested with high } \\
\text { bunds. }\end{array}$ & $\begin{array}{l}\text { Meertens et al. (1999), } \\
\text { Dunkelman et al. } \\
\text { (2018) }\end{array}$ & Lowland fringe-upland \\
\hline Rainfed upland & Upland & Rice plants are grown like maize. & Sekiya et al. (2015) & Upland \\
\hline
\end{tabular}

${ }^{\text {a }}$ Tanzania's rice agroecosystems fall under the three major categories

${ }^{\mathrm{b}}$ Irrigated and rainfed lowlands are further divided into subtypes based on the terrain and/or water source of each sub-category

${ }^{c}$ Diagne et al. (2013) classified Africa's rice-growing environments into three major categories: "irrigated lowland," "rainfed lowland," and "rainfed upland." They further identified two additional agroecosystems in unclear transition zones: "intensified lowland" between irrigated and rainfed lowlands and "lowland fringe (hydromorphic)" between rainfed lowland and upland. The authors' classification that corresponds to each subtype in Tanzania is indicated for comparison

basic cultivation techniques. The LMIS even employs power tillers, tractors, and combine harvesters.

\subsubsection{Rainfed lowland rice}

Approximately $70 \%$ of Tanzania's rice cultivated area is categorized as "rainfed lowland" (Diagne et al. 2013). This means that the vast majority of the rice fields scattered across the nation's diverse environments has been classified using this simplified terminology. While such simplification can advance our understanding of rice agroecology, much important information can be lost in the absence of a detailed analysis. Therefore, this review classifies the rainfed lowland agroecosystem into the following four subtypes according to water availability and farmers' water use techniques: plain grassland (gentle slopes in savannah grassland), catchment (gentle slopes in a catchment basin), flood plain, and narrow valley (see Table 1). Figure 2 presents a topographical distribution of the four subtypes across Tanzania, from northwest to southeast.

The plain grassland subtype is found mainly in the Mwanza, Shinyanga, and Tabora regions in the northwest on the large plateau (900-1000 m above sea level), which is a part of the East Africa Plateau (Meertens et al. 1999; Dunkelman et al. 2018). Farmers store rainfall for rice cultivation by making high bunds around fields. Each field has a long rectangular shape (e.g., 50-200 m long and 10-30 m wide) to allow for the effective use of ox plows. An aerial image from approximately $2000 \mathrm{~m}$ shows a great number of scale-like structures on the surface, which are actually rice fields surrounded by high bunds. Although rice yields are relatively low in these three regions (Meertens et al. 2003), these areas supply the nation's greatest amount of rice due to the large land area cultivated with rice plants. Rectilinear and broad valleys with gentle and straight slopes classified as a type of inland valleys by Rodenburg (2013) falls under this subtype. 
Table 2 Basic cultivation techniques and good agricultural practice for irrigated lowland agroecosystems

Basic cultivation techniques $(\mathrm{BCT})^{\mathrm{a}}$

Land preparation

- Clearing: 1-2 weeks before plowing

- Plowing: 1-2 weeks before puddling

- Bunding (or bund repairing)

- Puddling: 1-2 days before transplanting

- Leveling

- Application of organic manure ${ }^{c}$

Seedling nursery

- Raised seedbed ${ }^{\mathrm{c}}$

- Seedbed leveling ${ }^{\mathrm{c}}$

- Fertilizing of seedbed

- Seed selection ${ }^{\mathrm{c}}$

- Sowing of pre-germinated seeds ${ }^{\mathrm{c}}$

- Sowing rate: approximately $100 \mathrm{~g} \mathrm{~m}^{-2}$

- Irrigation of seedbed: 2-3-day intervals ${ }^{\mathrm{c}}$

Transplanting

- Young seedlings: 21 DAS

- Number of seedlings per hill: $2-3$ seedlings ${ }^{c}$

- Line transplanting

- Planting density: $30 \times 15 \mathrm{~cm}, 20 \times 20 \mathrm{~cm}$

- Gap filling: 1 WAT

Weeding

- First weeding: 2 WAT

- Second weeding: before panicle initiation

Fertilizer (basal)

Fertilizer (top dressing)

- First top dressing: 2 WAT

- Second top dressing: during panicle initiation

- Amount of fertilizer ${ }^{\mathrm{c}}$

Irrigation

- Intervals: 5-7 days ${ }^{\mathrm{c}}$

- Important timing 1: weeding ${ }^{\mathrm{c}}$

- Important timing 2: fertilizer application ${ }^{\mathrm{c}}$

- Important timing 3: heading stage ${ }^{c}$

- Depth: $>3 \mathrm{~cm}$ until 1 week before harvesting ${ }^{\mathrm{c}}$

- Depth: $>5 \mathrm{~cm}$ during heading ${ }^{\mathrm{c}}$

- Draining: 1 week before harvesting

Insect pest and disease

- Cultural control ${ }^{\mathrm{C}}$

- Chemical control ${ }^{\mathrm{C}}$

Harvest

- Timing: 30-35 days after heading ${ }^{\mathrm{c}}$

- Yield estimation ${ }^{\mathrm{c}}$

- Threshing ${ }^{\mathrm{c}}$

- Drying ${ }^{\mathrm{c}}$

- Storing
Good agricultural practice $(\mathrm{GAP})^{\mathrm{b}}$

- Land clearing: complete clearing of vegetation using a machete

- Tillage: using animal or motorized traction

- Bunding

- Pre-flooding ${ }^{\mathrm{d}}$

- Puddling: using a power tiller

- Leveling: using a wooden blank/hand hoe

- Fertilizer application: $100 \mathrm{~g}$ urea $\mathrm{m}^{-2}$

- Cultivar choice: certified seeds of TXD $306^{\mathrm{d}}$

- Nursery sowing

- Young seedlings: 21 DAS

- Line transplanting

- Planting density: $20 \times 20 \mathrm{~cm}$

- Thinning: 5-10 DAT ${ }^{\mathrm{d}}$

- Gap filling: 5-10 DAT

- First weeding: rotary weeding between rows followed by hand weeding in the row at 20 DAT

- Second weeding: rotary weeding between rows followed by hand weeding in the row at 40 DAT

- Herbicide application: using proper dose at proper time ${ }^{\mathrm{d}}$

- Basal fertilizer: $16 \mathrm{~kg} \mathrm{~N} \mathrm{ha}^{-1}$ and $40 \mathrm{~kg} \mathrm{P}_{2} \mathrm{O}_{5} \mathrm{ha}^{-1 \mathrm{~d}}$

- First top dressing: $32 \mathrm{~kg} \mathrm{~N}^{-1}$ at $20 \mathrm{DAT}$

- Second top dressing: $32 \mathrm{~kg} \mathrm{~N}^{-1}$ at $40 \mathrm{DAT}$

- Continuous until maturity ${ }^{\mathrm{d}}$

- Drainage: 10 days before harvest

${ }^{\text {a }}$ Sekiya et al. (2017) introduced basic cultivation techniques (BCT, a set of agronomic management techniques) into 31 irrigation schemes across Tanzania and increased paddy yields from 2.4 to $3.6 \mathrm{t} \mathrm{ha}^{-1}$ on average

${ }^{\mathrm{b}}$ Senthilkumar et al. (2018) proposed component technologies of good agricultural practice (GAP, an integrated set of agronomic management techniques) and confirmed their effectiveness using TXD306 not only in irrigated lowland farmer fields but also in rainfed lowland farmer fields in Kilombero

${ }^{\mathrm{c}}$ Component technologies used only in BCT but not in GAP

${ }^{\mathrm{d}}$ Component technologies used only in GAP but not in BCT

As the elevation decreases from the central region toward the southeast, the catchment subtype is found on gentle slopes in large river basins such as the Ruaha River (700-900 m above sea level) and Kilombero River
(500-700 $\mathrm{m}$ above sea level) in the Morogoro, Mbeya, and Rukwa regions (Kato 2007). Runoff is collected when the rainfall is adequate, and fields are flooded when the rainfall is excessive. Unlike farmers in plain grassland 


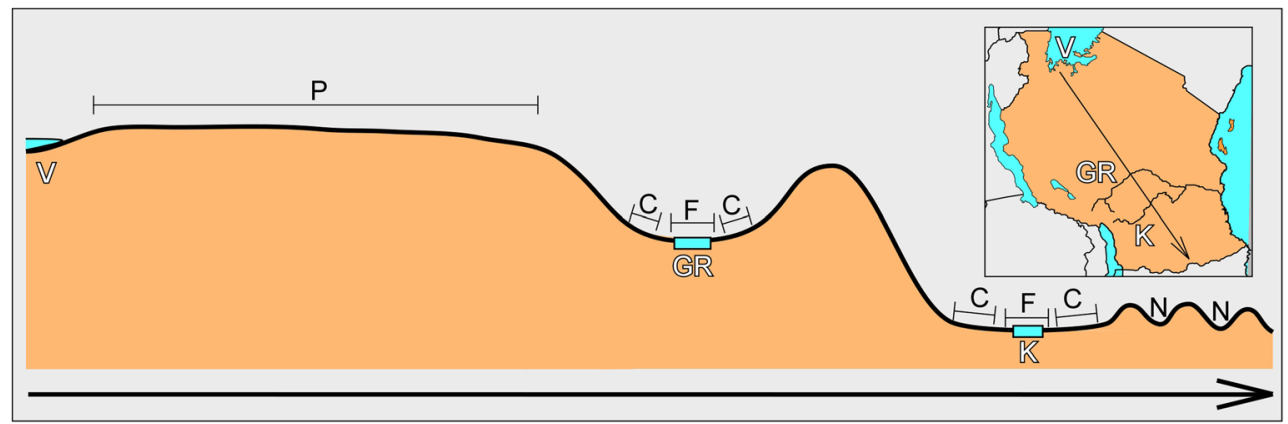

Fig. 2 The topographical distribution of rainfed lowland rice agroecosystems in Tanzania. A cross section is depicted along the arrow in the small map. The four subtypes described in Table 1 are indicated by initial: $\mathrm{P}=$ plain grassland; $\mathrm{C}=$ catchment; $\mathrm{F}=$ flood plain; $\mathrm{N}=$ narrow valley. Three major water bodies along the axis are also indicated by initial: V = Lake Victoria; GR = Great Ruaha River; $\mathrm{K}=$ Kilombero River

\section{Rice market}

areas, catchment farmers rarely make bunds to allow for an easy inflow of runoff and floods into their fields. The flood plain subtype is found along those large rivers (Kadigi et al. 2004; Kangalawe and Liwenga 2005). Because the rivers provide a secure water supply, farmers rarely practice water-storing techniques such as bunding. The narrow valley subtype is found on flat narrow valley bottoms in inland valleys with moderately steep convex side slopes in coastal regions such as Tanga, Pwani, Lindi, Mtwara, and Zanzibar (Rodenburg 2013); fields are occasionally surrounded by bunds here.

\subsubsection{Rainfed upland rice}

Typical and traditional upland rice plants are mainly grown in the hilly areas of Ulanga rural district and Kilombero district in the Morogoro region (Sekiya et al. 2015). Because rice plants in rainfed lowlands are grown under conditions similar to rainfed uplands when the rainfall is insufficient, rainfed lowland rice farmers sometimes regard their agroecosystems as rainfed upland. Upland rice seeds are broadcast and grown without the application of chemical fertilizer; therefore, the national average yield of rainfed uplands is as low as $0.5 \mathrm{t} \mathrm{ha}^{-1}$ (MAFC 2009). New Rice for Africa cultivars (NERICAs) were released for the rainfed upland agroecosystem in 2009 and have been disseminated rapidly in the Morogoro, Tanga, Lindi, and Mtwara regions due to a training and extension program developed by MATIs (Sekiya et al. 2015). NERICAs are also adopted by farmers in rainfed lowland agroecosystems, likely due to their high yield potential under limited water (AfricaRice 2008) and soil nutrient (Mghase et al. 2010) conditions, early maturity that enables the completion of plant growth within a short period of rainy season (Sekiya et al. 2013), relatively good eating quality (Sekiya et al. 2013) and resistance against parasitic weeds (Rodenburg et al. 2015).

\subsection{Rice value chain}

Rice is distributed nationwide in Tanzania. The major cities for rice retail, wholesale, assembly, and trade flows are shown in Fig. 3, which is based on the literature (FEWS NET 2009; Senda 1999). Mwanza, Shinyanga, Tabora, Moshi, Morogoro, Kilombero, Mbeya, Sumbawanga, and Mpanga represent the major rice supply cities. The nation's major rice consumption cities, where many non-farming consumers reside, include Dodoma, Dar es Salaam, Arusha, Zanzibar, Lindi, Mtwara, Musoma, and Bukoba. The consumer market for Tanzanian rice extends to neighboring countries such as Kenya, Uganda, Rwanda, Congo (DRC), Zambia, and Malawi. The price gap between the supply and consumer market is the major driving force for the nationwide distribution of rice (Nkonya and BarreiroHurle 2012; Minot 2010; Senda 1999). Although rice distribution and trade flows can be qualitatively evaluated (Fig. 2) by interviewing rice industry stakeholders, quantitative evaluation is difficult due to a lack of official Tanzanian statistics.

Various stakeholders are involved in Tanzanian rice distribution, and rice is delivered from producers to consumers via a number of transactions. Figure 4 presents a model of the rice value chain constructed based on the literature (Nkonya and Barreiro-Hurle 2012; Eskola 2005; Senda 1999). Brokers, wholesalers, and retailers of various sizes operate at the village, district, and regional levels, and a number of transporters mediate among the stakeholders. The ECI (2003) reported a case in which rice was delivered from producers to consumers via 35 cash transactions. The increase in transaction costs due to the intervention of many stakeholders is one of the factors causing the high market prices for rice (Nkonya and Barreiro-Hurle 2012; Eskola 2005; Nzomoi and Anderson 2013). 
Fig. 3 Rice distribution flow in Tanzania. Black circle $=$ city dealing with rice assembly, wholesale, and retail; white triangle $=$ city dealing with rice assembly and wholesale; white square $=$ city dealing with rice wholesale and retail; white circle $=$ city dealing with rice retail only; thick arrow $=$ large flow of rice; thin arrow $=$ small flow of rice

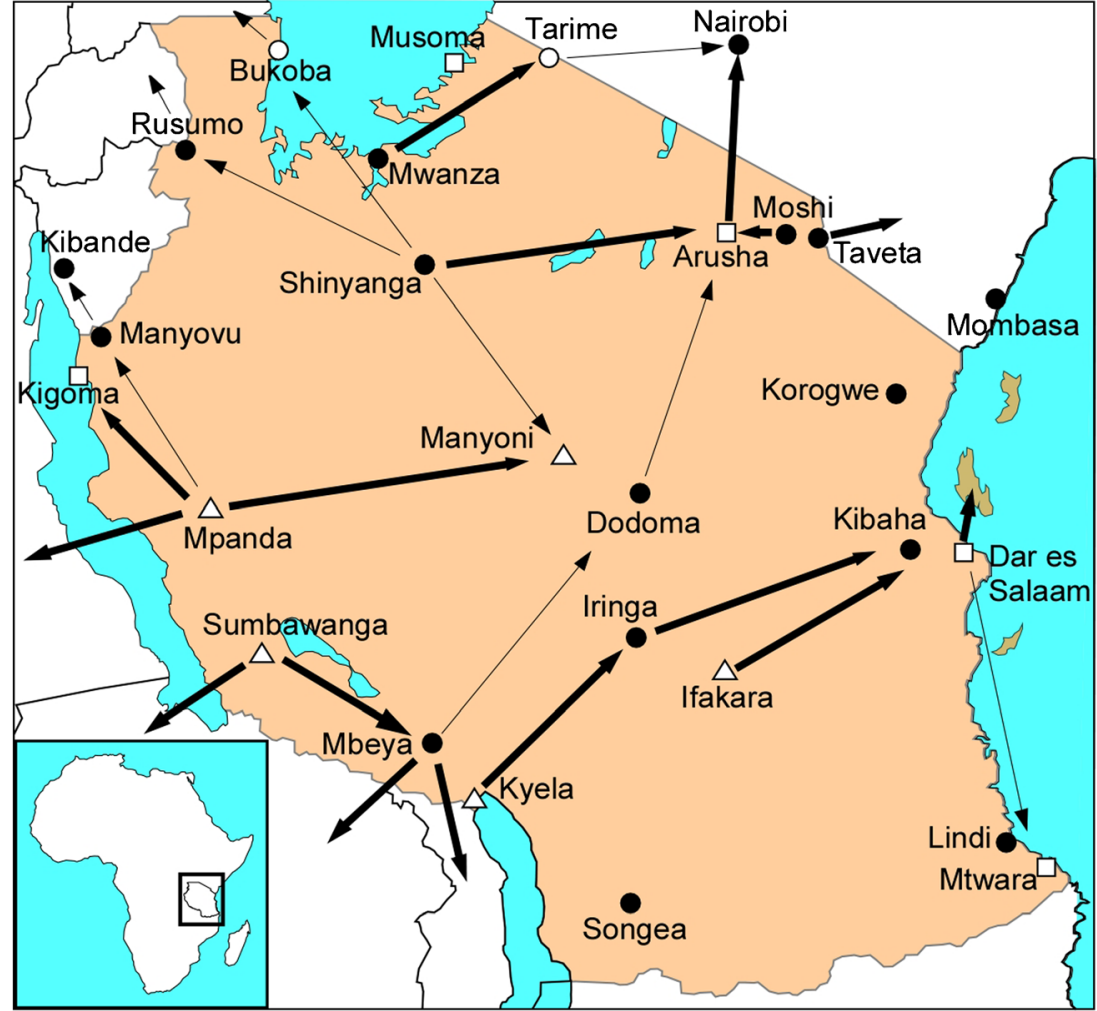

\subsection{Rice prices}

Though the prices of imported rice are lower than the prices of local rice, consumers are likely to choose domestic products due to strong taste and aroma preferences. In addition to the accumulated transaction cost, Tanzania's long-distance transport and underdeveloped infrastructure also contribute to the increased market prices of rice, further widening the price gap between imported and local rice (Minot 2010; Nzomoi and
Anderson 2013; Therkildsen 2011). This price gap is a prime factor motivating domestic traders to import Thai rice from the international market. Although the Tanzanian government imposes a $75 \%$ tariff on imported rice on behalf of the East African Community, the rice is still distributed at lower prices than local rice (Demont 2013; Nzomoi and Anderson 2013). Demont (2013) analyzed the national rice development strategies of 19 African nations and found that imported rice is preferred by West African consumers in terms of price and
Fig. 4 Rice value chain in Tanzania

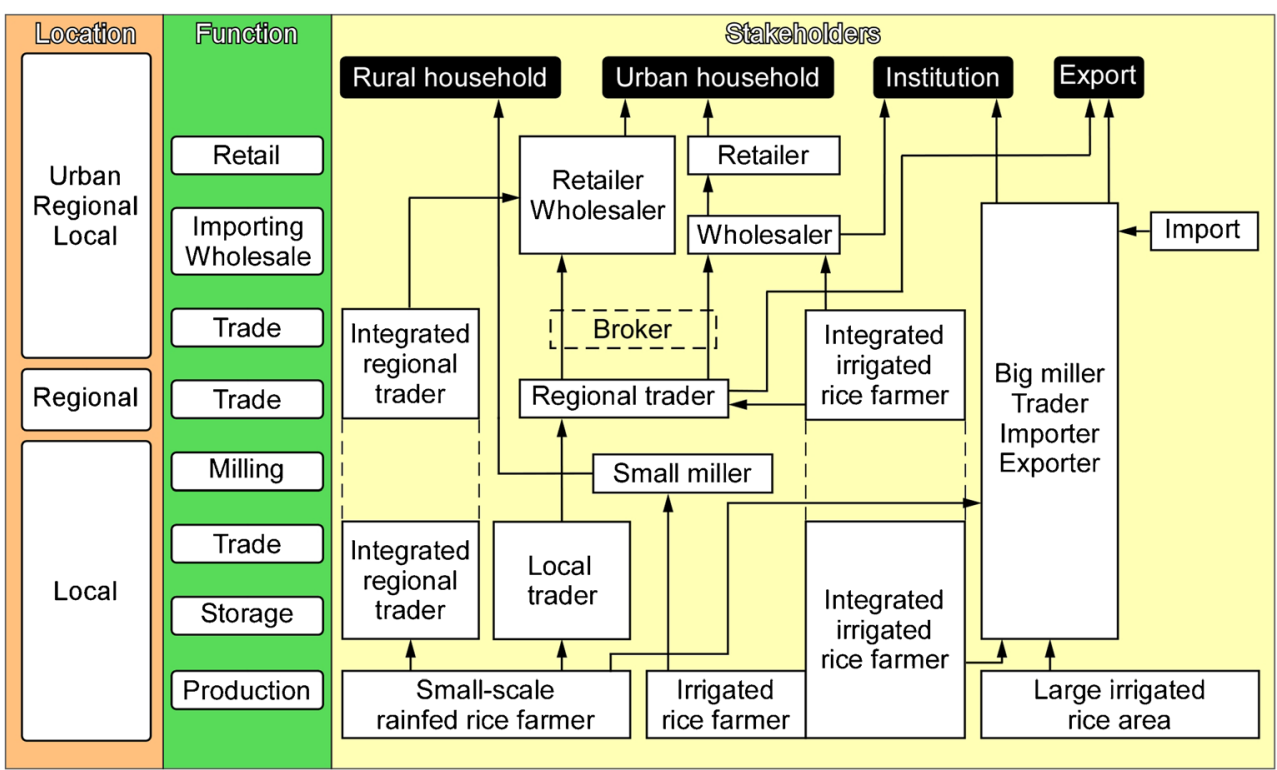


taste, while Tanzanian consumers tend to prefer high-quality local rice to inexpensive, low-quality imported rice. Nzomoi and Anderson (2013) reported that local rice has a price premium of approximately $20 \%$ over imported rice in Tanzania.

Tanzanian consumers prefer the quality of local rice, with its market price varying according to its quality. Senda (1999) interviewed rice wholesalers and retailers in eight cities and reported that the ratio of the highest to the lowest price in each market ranged from 1.02 to 1.79 . In Tanzania, rice quality is closely associated with the region of production, and rice from Mbeya (Kyela), Magugu, and Kilombero is traded as highquality brands at higher prices. According to stakeholders in the rice value chain, grain appearance (size and color) as well as aroma and taste (when the rice is steamed) are the major attributes Tanzanian consumers consider when selecting a rice brand. Sekiya et al. (2013) conducted a sensory analysis of cooked grain quality (color, fluffiness, taste, and aroma) and reported that Tanzanian consumers gave significantly higher scores to Mbeya rice over imported rice. The authors also reported that farmers in the Mbeya region grew a highyielding cultivar, Mwangulu, in only small parts of their fields for emergencies due to its poor quality. Consumer quality preferences and resultant price gaps are broadly found in several crops; a detailed analysis was conducted for the common bean (Mishili et al. 2011).

\section{Rice research}

\subsection{History of rice research}

Rice research in Tanzania began at the Mwabagole Rice Station near Lake Victoria in 1935 (Kanyeka et al. 2005; Mwaseba 2005). From the 1930s to the 1950s, the main mandate of the rice research program was to screen traditional cultivars, introduce foreign cultivars, and improve cultivation techniques (Mwaseba 2005). However, the justification for the rice research program gradually disappeared due to the decline of rice production in the country, and the program was suspended in 1955 (Meertens et al. 1999). The rice research unit was revived at the Agricultural Research Institute Ilonga (ARI-Ilonga) in Morogoro in 1965 and was transferred in 1975 to the Kilombero Agricultural Training Research Institute (KATRIN, currently known as the "Tanzania Agricultural Research Institute Ifakara," or TARI-Ifakara; Mwaseba 2005). Thereafter, rice research units were established at ARI-Dakawa in Morogoro, ARI-Ukiriguru in Mwanza, ARI-Uyole in Mbeya, and ARI-Naliendele in Mtwara. The national rice research program is coordinated by KATRIN. In 2018, the ARI was restructured as the Tanzania Agricultural Research Institute (TARI), and each institute was renamed accordingly: TARI-Dakawa, TARI-
Ukiriguru, TARI -Uyole, TARI-Naliendele, and TARIIfakara.

During the 1970s, its main task was still the screening of traditional cultivars and the introduction of foreign ones, especially from the International Rice Research Institute (IRRI; Kanyeka et al. 2005). In the 1980s, their focus shifted from traditional to modern breeding, and TARI-Dakawa developed TXD85, TXD88, and TXD306 in the Supa improvement project (Supa being one of the most popular traditional cultivars) initiated in 1983 (Kanyeka et al., 2004, 2005; Msomba et al. 2004). In the 2000s, several cultivars resistant to the rice yellow mottle virus (RYMV) disease were developed through mutation breeding using radiation (Luzi-Kihupi et al. 2008). NERICA1 to NERICA18 along with other upland rice lines were introduced by AfricaRice through the International Network of Genetic Evaluation (INGER-Africa) from 2003 to 2006 (AfricaRice 2008). After evaluation, NERICA1, NERICA2, NERICA4, NERICA7 and WAB450-12-2-BL1DV4 were released in 2009 (Mghase et al. 2010; Sekiya et al. 2015). Rainfed lowland cultivars Komboka and Tai were introduced by the IRRI in 2013, and more recently, TARIDakawa developed salt-tolerant cultivars SATO1 and SATO9. Table 3 lists the cultivars released by the rice research program in Tanzania.

A large-scale farming system research program was implemented in rainfed rice fields in Sukumaland (Mwanza, Shinyanga, and Tabora) through cooperation between ARIUkiriguru and the Netherlands from the 1980s to the 1990s (Meertens, 1999, 2003; Meertens et al., 1999, 2003). A series of projects was conducted in rainfed lowland fields in the Lindi and Mtwara regions through cooperation between ARI-Naliendele and Belgium's Leuven University from the 1990s to the 2000s (Kafiriti et al. 2003a, b, c). The Sokoine University of Agriculture and the University of Dar es Salaam conducted rice research in an attempt to estimate the impact of water use in rice production on river basin hydrology (Kadigi et al., 2004, 2008; Mdemu et al. 2004; Mwakalila 2005; Rajabu 2007) as well as to evaluate the social impact of the rice research program (Mwaseba 2005; Mwaseba et al., 2006, 2007). In 2005, Tanzania became one of the principal locations of AfricaRice from which its staff member coordinated the now defunct Eastern and Central African Rice Research Network (ECARRN). After the opening of a regional office in Dar es Salaam, AfricaRice began a series of activities specific to Tanzania's rice agroecosystems such as rice breeding for lowland, upland and high-altitude systems, agricultural mechanization, rice value chain development, and rice production training (AfricaRice 2014).

\subsection{Traditional rice cultivars}

Most of the rice cultivars grown in Tanzania are considered traditional, and the use of improved cultivars should be 
Table 3 Rice cultivars released in Tanzania

\begin{tabular}{|c|c|c|c|}
\hline Year & Cultivar & Origin & References \\
\hline 1960 & Supa & India & Singh et al. (2013) \\
\hline 1972 & $\begin{array}{l}\text { Gamti (Tunduru), Faya } \\
\text { Theresa }\end{array}$ & Land race & Kanyeka et al. (2005) \\
\hline 1973 & $\begin{array}{l}\text { Kihogo red (Morogoro) } \\
\text { Kihogo Selection }\end{array}$ & Land race & \\
\hline \multirow[t]{2}{*}{1974} & Afaa Mwanza & Land race & \\
\hline & IR5, IR8, IR 20, IR 22 & IRRI & \\
\hline 1976 & Afaa Kilombero & Land race & \\
\hline 1983 & Dakawa83 & IRRI & Singh et al. (2013), \\
\hline 1984 & IR54, IR579 & IRRI & Dalrymple (1986) \\
\hline 1985 & $\begin{array}{l}\text { Selemwa } \\
\text { Katrin }\end{array}$ & $\begin{array}{l}\text { Faya Theresa } \times \text { IR8 } \\
\text { India, R.P. 143-4 } \\
\quad(\text { IET 2397; H.R. } 19 \times \text { IR8) }\end{array}$ & $\begin{array}{l}\text { Kanyeka et al. (2005), } \\
\text { Dalrymple (1986) }\end{array}$ \\
\hline 1985 & Subarimati & IRRI $^{\mathrm{a}}$ & Singh et al. (2013) \\
\hline 1988 & IR64 & IRRI $^{\mathrm{a}}$ & Kanyeka et al. (2005) \\
\hline 1999 & TXD85 & $\begin{array}{l}\text { Supa } \times \text { KM67 } \\
\quad(\text { early maturing North Korean cultivar) }\end{array}$ & $\begin{array}{l}\text { Kanyeka et al. (2004), } \\
\text { Kanyeka et al. (2005) }\end{array}$ \\
\hline \multirow[t]{2}{*}{2002} & TXD88 & $\begin{array}{l}\text { TXD85 } \times \text { Subarimati } \\
\text { (North Korean cultivar) }\end{array}$ & \\
\hline & TXD306(SARO5) & Supa/Pyongyang8 $\times$ Subarimati/Supa & $\begin{array}{l}\text { Msomba et al. (2004), } \\
\text { Singh et al. (2013) }\end{array}$ \\
\hline 2006 & Kalalu, Mwangaza & Supa mutant & Singh et al. (2013) \\
\hline 2009 & $\begin{array}{l}\text { NERICA1, NERICA 2, } \\
\text { NERICA4, NERICA 7, } \\
\text { WAB450-12-2-BL1-DV4 }\end{array}$ & AfricaRice & \\
\hline 2013 & Komboka, Tai & IRRI & Singh et al. (2013) \\
\hline 2016 & SATO1, SATO9 & $\begin{array}{l}\text { Pokkali (IR-4595-4-1-1-3), } \\
\text { IR67076-2B-21-2, CSR27 } \\
\text { (CSR88IR-7), TXD306, IR64, IR56, } \\
\text { Thailand }\end{array}$ & \\
\hline
\end{tabular}

IRRI International Rice Research Institute, AfricaRice Africa Rice Center limited. However, no comprehensive survey of rice cultivars across the county has been conducted, with two partial exceptions. Satoh et al. (1990) collected paddy samples from rice fields and the storehouses of farmers and retailers in major rice-producing regions in 1988 and identified 121 strains, most of which were traditional (see Table 4). The Kilimanjaro Agricultural Training Centre (KATC) collected paddy samples from extension officers who had come from across the country to participate in training courses for irrigated lowland rice cultivation; most of the cultivars were traditional. The KATC samples were handed over to TARI-Ifakara (which was then KATRIN), and the basis of the seed collection program was established using the samples.

Genetic characterization of traditional cultivars has been left out until recently (Mogga et al. 2018; Suvi et al. 2019). Probably due to this ignorance, many confusions are found in the definition of traditional cultivars. For example, although Supa was introduced from India in 1960 (Table 3), this cultivar is often referred to as a landrace in Tanzania (e.g., Suvi et al. 2019). The same story can be applied to other cultivars such as India and Zambia as shown in Table 4. Although traditional cultivars include both landraces and introduced foreign cultivars, this terminology is consistently used in this review as long as cultivars have been accepted and grown for many years by rice farmers in Tanzania. Because farmers have tendency to give original names to newly introduced cultivars, one cultivar is often recognized as a different cultivar in a different region, adding some confusion to the characterization of traditional cultivars (e.g., Kalamata in Kahama is called Malamata in Shinyanga and Fwaja in Kyela, and Cherehani in Mbeya is called Mkombozi in Magugu). Although traditional cultivars have been used as local checks in many agronomic studies (e.g., Rodenburg et al. 2016; Tippe et al. 2017), their morphological, physiological, and ecological characterization has been also left out. The information about agronomic traits of traditional cultivars is still dependent on farmers' knowledge and experiences (e.g., Meertens et al. 1999; Sekiya et al. 2013). 
Table 4 Traditional rice cultivars in Tanzania reported in four different literatures

\begin{tabular}{|c|c|c|c|}
\hline Satoh et al. (1990) ${ }^{\mathrm{a}}$ & Meertens et al. (1999) ${ }^{\mathrm{b}}$ & Mogga et al. $(2018)^{\mathrm{c}}$ & Suvi et al. (2019) ${ }^{\mathrm{d}}$ \\
\hline Afaa & Faya & Supa & Afaa Mwanza \\
\hline Afaa Mwanza & Kahogo & & Chamota \\
\hline Arusha & Lugata & & Cherehani \\
\hline Ausbin & Pishauri & & Faya mzinga \\
\hline Faya & Rangi mbili & & Gombe \\
\hline Gamti & Sindano & & Kalamata \\
\hline Horonadi & Supa & & Kalubangala \\
\hline India & Tondogoso & & Kalundi \\
\hline India Rangi & & & Kihogo red \\
\hline Kibawa & & & Kisegese \\
\hline Kibibi & & & Limota \\
\hline Kihogo & & & Masantula \\
\hline Kijicho & & & Mbawa ya njiwa \\
\hline Kilombero & & & Mbawa mbili nyekundu \\
\hline Kisaki & & & Mbega \\
\hline Kivuli & & & Moshi \\
\hline Kula Na Bwana & & & Mpaka wa bibi \\
\hline Lakata Kihogo & & & Mwanza \\
\hline Limoto & & & Mzinga \\
\hline Malbora & & & Rangi mbili nyekundu \\
\hline Mka Wa Ngawa & & & Ringa \\
\hline Mkia Wa Nyumba & & & Serena \\
\hline Moshi & & & Shigo ya mwalil \\
\hline Moshi (Sigara) & & & Sindano nyeupe \\
\hline Mwangle & & & Sumbawanga \\
\hline Mwasungo & & & Supa \\
\hline Ngohi & & & Turiani \\
\hline Ringa & & & Wahiwahi \\
\hline Riziki & & & Zambia \\
\hline \multicolumn{4}{|l|}{ Semanini } \\
\hline \multicolumn{4}{|l|}{ Senga senga } \\
\hline \multicolumn{4}{|l|}{ Sindano } \\
\hline \multicolumn{4}{|l|}{ Supa } \\
\hline \multicolumn{4}{|l|}{ Supa Mwasungo } \\
\hline \multicolumn{4}{|l|}{ Tarabizuna } \\
\hline \multicolumn{4}{|l|}{ Wahiwahi } \\
\hline \multicolumn{4}{|l|}{ Wamba } \\
\hline Zira & & & \\
\hline
\end{tabular}

${ }^{\text {a }}$ Satoh et al. (1990) collected paddy samples from rice fields and storehouses of farmers and retailers in major rice-producing regions (see Fig. 3) and identified 121 strains, most of which were traditional

${ }^{\mathrm{b}}$ Meertens et al. (1999) reported that these traditional cultivars were the most important ones for rice farmers in Sukumaland (Mwanza, Shinyanga, and Tabora) during the 1990s

${ }^{\mathrm{c}}$ Mogga et al. (2018) conducted a genome-wide association study using 59 rice genotypes including a Tanzanian traditional cultivar Supa and identified 22 DArTseq-derived SNP loci significantly associated with rice grain quality traits

${ }^{\mathrm{d}}$ Suvi et al., (2019) identified a considerable genetic diversity among 54 rice accessions including 29 Tanzanian traditional cultivars using SSR markers 


\subsection{Challenges in rice breeding}

Tanzania's rice research program faces the serious challenge of revising the nation's breeding strategy. Traditionally, improving rice yields was a major rice breeding target. To accomplish this goal, foreign elite lines and/or cultivars have been introduced into farmers' fields after an evaluation and/ or crossed with local cultivars to develop new lines. During the 1970s, the cultivars introduced by the IRRI were widely grown in the state-run schemes (Dalrymple 1986). However, most of the IRRI cultivars are no longer found in farmers' fields except for IR64, which is grown in a few irrigation schemes in the Kilimanjaro region (Sekiya et al. 2013). Kanyeka et al. (2005) reported that the locally bred cultivars Afaa Mwanza, Selemwa, and Katrin were also introduced into those state-owned schemes but were rejected by small-scale farmers. The authors argued that the rejection was due to poor grain quality. Mwaseba et al. (2006) interviewed rice farmers in Kilombero and Kyela and reported that TXD85 and TXD88 were also rejected by farmers because of their weak marketability due to poor grain quality. The authors further claimed that the high costs of cultural management also contributed to the rejection. In the previous breeding programs, qualityrelated traits might have been underestimated or even ignored during the screening process due to the overemphasis on highyielding ability.

NERICA1 seeds were distributed to upland rice farmers in 15 districts across Tanzania along with a 2-day residential training course in 2011 and 2012 (Sekiya et al. 2015). It seems likely that the cultivar failed to diffuse beyond those beneficiary farmers in districts such as Kyela, Mvomero, Ulanga, Morogoro, Muheza, and Korogwe (Kangile et al. 2018; Hashim et al. 2018); the cause of the failure is still unclear. However, NERICA1's grain quality may have discouraged farmers to adopt the cultivar because Tanzanian consumers gave significantly higher scores to Mbeya rice over NERICA1 even though NERICA1 was ranked higher than imported rice (Sekiya et al. 2013). Unfavorable soil hydraulic properties (Sekiya et al. 2013) and parasitic weeds (Rodenburg et al., 2010, 2014; Schut et al. 2015) may have also contributed to the failure.

It is reasonable to argue that rice farmers in Tanzania pay close attention to rice market trends, which are strongly influenced by consumer preference for the grain quality of traditional cultivars. As mentioned, Tanzanian rice market developments motivated small-scale farmers to engage in rice production (Kadigi et al. 2004; Kato 2007; Meertens et al. 1999). In the Mwanza and Shinyanga regions, rice spread rapidly and widely as a good alternative to cotton after international cotton prices fell (Meertens et al., 1999). Kafiriti et al. (2003b) investigated farmers' preferences for rice grain quality, revealing that most farmers put a greater emphasis on grain quality than on yielding ability when selecting cultivars. Nzomoi and
Anderson (2013) interviewed rice farmers in Mwanza, Shinyanga, Tabora, Mbeya, and Morogoro and revealed that approximately half of the rice farmers regarded rice as the most important cash crop. Thus, we strongly agree with Kafiriti et al. (2003b) that a revision of the breeding target, which is greatly oriented toward improving yielding ability, is necessary.

Recent initiatives of the rice research program are worthy of close attention. TXD306, one of the recently released cultivars, has high-yielding potential, inherited from foreign cultivars, and good palatability, inherited from a traditional cultivar (Msomba et al. 2004). Farmers' acceptance of TXD306 is reported to be sufficiently high, and it is gradually spreading out from the Morogoro region, where TARI-Ifakara (the cultivar's breeding institution) is located (Nakano and Kajisa, 2013, 2014; Nzomoi and Anderson 2013; Nkuba et al. 2016). However, the yielding ability of TXD306 seems to be greatly reduced in rainfed conditions (Mwaseba et al. 2007; Nakano and Kajisa, 2013, 2014). Additional study is needed to determine whether TXD306 will continue to be accepted by famers in the remainder of Tanzania because a high percentage of the nation's rice-growing area is still under rainfed conditions. Komboka, one of the most recently released cultivars, is promising in terms of its yielding ability under rainfed conditions. Singh et al. (2013) argued that Komboka should be accepted by rice farmers due to its aroma as well as its superior yield compared with TXD306. However, according to Kangile et al. (2018), few farmers grew Komboka in Kahama, Kilombero, and Kyela districts in 2017. The authors attributed this low rate of adoption to the non-availability of Komboka seeds. Fiamohe et al. (2016) conducted experimental auctions in Dar es Salaam and Morogoro markets, reporting that consumer willingness to pay for Komboka is low compared with local cultivars such as Supa and Kalamata. This implies that seed availability might have little effect on the low adoption rate of this cultivar due to low acceptance by consumers. Further research is needed to measure the acceptance of Tai, SATO1, and SATO9 in rice markets.

\subsection{Challenges in rice agronomy}

Recently, major progress has been made in the agronomic study of irrigated lowland rice. Nhamo et al. (2014) proposed that yield gains obtained through improved rice cultivars can be enhanced through application of Good Agricultural Practice (GAP), which is an integrated set of agronomic management techniques that enhance soil fertility and water availability as well as control weeds in East and Southern Africa. Senthilkumar et al. (2018) proposed component technologies of GAP as shown in Table 2 and confirmed their effectiveness using TXD306 not only in irrigated lowland farmer fields but also in rainfed lowland farmer fields in Kilombero. Prior to Senthilkumar et al. (2018), Sekiya et al. 
(2017) introduced basic cultivation techniques (BCT; a set of agronomic management techniques similar to GAP shown in Table 2) into 31 irrigation schemes across Tanzania and increased paddy yields from 2.4 to $3.6 \mathrm{t} \mathrm{ha}^{-1}$ on average. No improved cultivar was introduced during their study; the yield increment was achieved with traditional cultivars. Therefore, the dissemination of GAP and BCT is expected to improve rice farmers' ability to supply commercially viable rice (TXD306 or traditional cultivars) to the nation's markets under irrigated lowland conditions.

However, the effectiveness of GAP and BCT under rainfed lowland conditions should be open to debate. Senthilkumar et al. (2018) showed that among the GAP component technologies, the application of basal fertilizer and drainage have significant impact on grain yields of TXD306. Their experimental site, Kilombero, is classified into the catchment subtype where rice fields are flooded when rainfall is excessive (Table 1). In general, drainage is one of the most important technologies to achieve high rice yields under excessive moisture conditions. The significant effect of drainage may have been observed due to the hydrological characteristics of the experimental site. Further investigation is needed to confirm the effectiveness of GAP and BCT in other subtypes especially narrow valley and plain grassland subtypes.

Some traditional cultivars have seemly obtained capabilities to adapt to specific agroecosystems, and rice farmers have been growing different cultivars for different environments based on farmers' empirical analysis on the characteristics of cultivars. For example, Meertens et al. (1999) observed in Mwanza that traditional cultivars, such as Kilombero, were grown in water-limited conditions (plain grassland subtype) while Tondogoso and Lugata were popular in the valley bottom where sufficient water was available (narrow valley subtype). Sekiya et al. (2013) observed in Mbeya that rice farmers grew an unpopular cultivar Mwangulu for emergencies because it was able to survive harsh growing conditions. By taking advantage of the unique characteristics of traditional cultivars, some of the component technologies in GAP and $\mathrm{BCT}$ such as land preparation and transplanting could be modified, and the development of GAP and BCT for rainfed lowland conditions could become possible. Moreover, the use of the unique characteristics of traditional cultivars may strengthen the effectiveness of GAP and BCT under irrigated lowland conditions as well. Sekiya et al. (2015) compared the yielding ability of traditional cultivar Wahiwahi with the abilities of TXD306, IR64, and NERICA1 under irrigated conditions in Kilimanjaro and reported that Wahiwahi transplanted in January, February, August, and November yielded more than the other three cultivars transplanted in each month. The detailed results are shown in Fig. 5.

\subsection{A way forward}

This review proposes a new research framework for rice production in Tanzania that is greatly oriented toward meeting consumers demands (Fig. 6). The framework is constructed on two fundamental ideas: (1) both breeding and agronomy should have specific research targets for each of the agroecosystems and (2) genetic resources of traditional cultivars should be fully explored for both breeding and agronomy.

In the irrigated lowland agroecosystem, the breeding path of TXD306 (traditional cultivars crossed with foreign elite lines) should be followed to breed new cultivars with good grain quality and high-yielding ability. Mogga et al. (2018) recently conducted a genome-wide association study using 59 rice genotypes from IRRI (4 cultivars), AfricaRice (22 cultivars), International Center for Tropical Agriculture (1 cultivar), Uganda (21 cultivars), Madagascar (2 cultivars), Mali ( 4 cultivars), Sudan ( 3 cultivars), and Tanzania ( 2 cultivars, see Table 4) and identified 22 DArTseq-derived SNP loci significantly associated with rice grain quality traits. The proposed breeding path should be accelerated through the genome-wide association study with other traditional cultivars in Tanzania. The same path should be followed in the rainfed
Fig. 5 Paddy yields of Wahiwahi, TXD306, NERICA1, and IR64 transplanted monthly from January to December in 2011 in Kilimanjaro, Tanzania. Red circle with red thick line = Wahiwahi; blue triangle with blue thin line $=$ TXD306; orange square with orange thin line = NERICA1; green diamond with green thin line $=$ IR64. Data were derived from Sekiya et al. (2015)

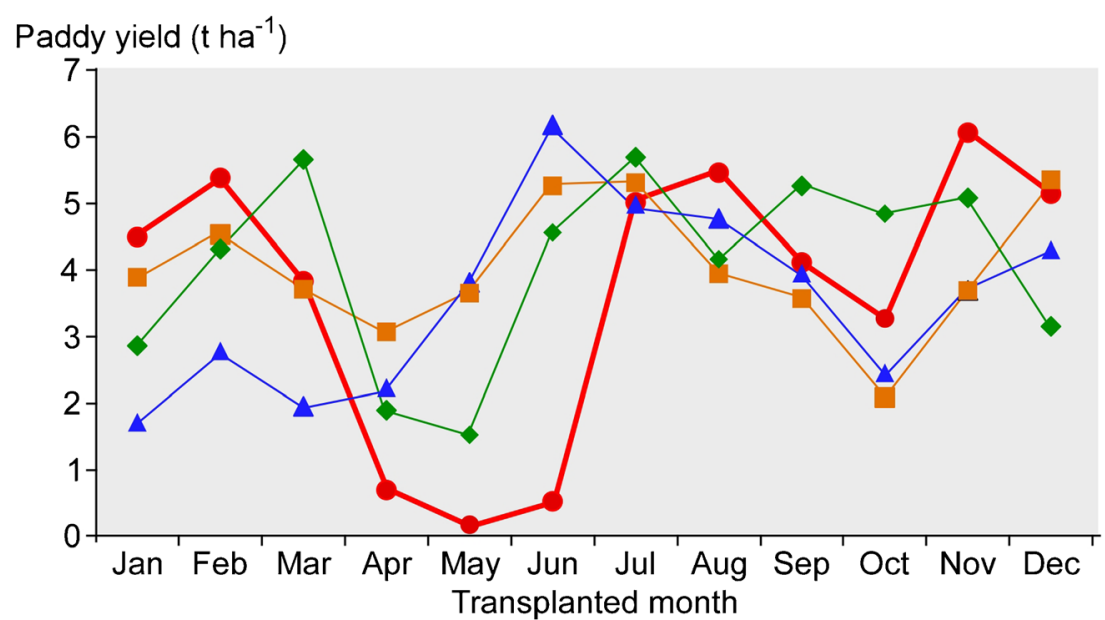




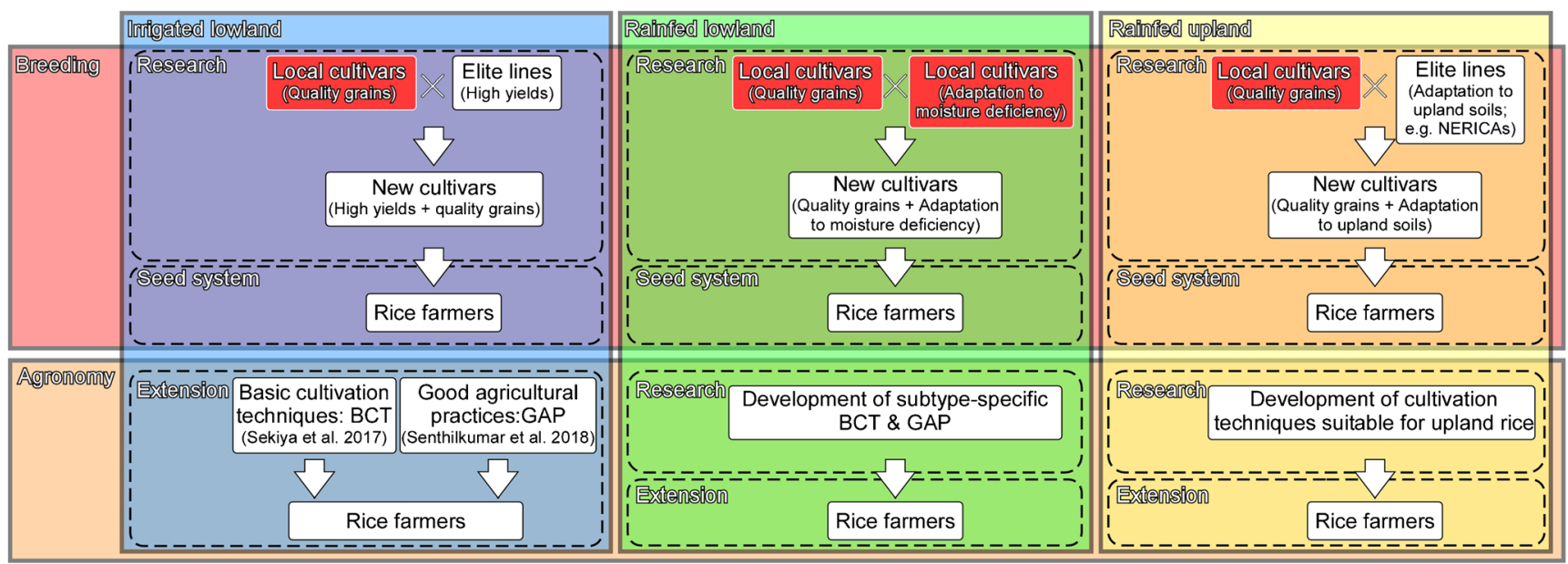

Fig. 6 Conceptual framework of proposed research targets for rice production in Tanzania. Research targets in breeding and agronomy are contained in pink and orange boxes, respectively. Specific research targets for irrigated lowland, rainfed lowland, and rainfed upland are aggregated in blue, green, and yellow boxes, respectively. In each of the agroecosystems, a seed system must be developed if breeding efforts are to be successful, and a farmer-to-farmer extension approach proposed by Sekiya et al. (2015) should be introduced to disseminate cultivation techniques

(OFs). Nakano et al. (2018) analyzed a unique 5-year household-level panel data set in one of the 31 irrigation schemes, Ilonga, and revealed that the FTF extension approach was effective and created a performance gap between trained and non-trained farmers. In the rainfed lowland agroecosystem, GAP and BCT should be modified for each subtype. Physiological and ecological characteristics of traditional cultivars adapted to each subtype should be fully utilized for the modification. After the modification of GAP and BCT, the FTF extension approach should be also prepared accordingly. In the rainfed upland agroecosystem, agronomic management techniques of NERICA1 production proposed by Sekiya et al. (2015) should be modified for each cultivar developed.

\section{Conclusion}

In Tanzania, consumers prefer the grain quality of traditional rice cultivars, and as a result, traditional rice cultivars are sold at premium prices relative to imported rice in the nation's rice market. However, improving yields by introducing foreign elite lines or crossing them with local cultivars has been a major task for rice research institutes. Farmers have rejected most of the previously released cultivars due to their poor grain quality. The recently released TXD306 is a promising cultivar with good grain quality from a traditional cultivar and high-yielding ability from foreign elite lines. The integrated set of agronomic management techniques such as GAP and $\mathrm{BCT}$ is effective in increasing rice yields of TXD306 and traditional cultivars under irrigated lowland conditions. The application of technical packages to rainfed lowland conditions still requires some additional investigation due to the wide range of hydrological characteristics across subtypes in 
this agroecosystem. We propose the market-oriented research framework for Tanzania's rice production in which research targets are made specifically for agroecosystem, and genetic resources of traditional cultivars are fully explored. This study has shown the importance of multidisciplinary approach in improving rice production in Tanzania.

Acknowledgments The authors thank two anonymous reviewers for their insightful comments on earlier version of our manuscript.

Funding information This work was supported by JSPS KAKENHI Grant Number 15556653.

\section{Compliance with ethical standards}

Conflict of interest The authors declare that they have no conflict of interest.

\section{References}

AfricaRice (2008) NERICA: the new rice for Africa - a compendium. http://www.africarice.org/publications/nerica-comp/Nerica\% 20Compedium.pdf. Accessed 12 December 2019

AfricaRice (2014) Africa Rice Center Development Plan 2014-2020. https://issuu.com/africaricecenter/docs/centerdev-plan_combined_ 0s-1p. Accessed 12 December 2019

Carpenter AJ (1978) The history of rice in Africa. In: Buddenhagen IW, Persley GJ (eds) Rice in Africa. Academic Press, New York, pp 310

Dalrymple DG (1986) Development and spread of high-yielding rice varieties in developing countries. Agency for International Development, Washington, D.C. http://books.irri.org/9711041596_ content.pdf. Accessed 12 December 2019

de Bont C (2018) The continuous quest for control by African irrigation planners in the face of farmer-led irrigation development: the case of the lower Moshi Area, Tanzania (1935-2017). Water Altern 11(3): 893-915 http://www.water-alternatives.org/index.php/alldoc/ articles/vol11/v11issue3/469-a11-3-22. Accessed on 17 January 2020

Demont M (2013) Reversing urban bias in African rice markets: a review of 19 national rice development strategies. Glob Food Secur 2(3): 172-181. https://doi.org/10.1016/j.gfs.2013.07.001

Diagne A, Amovin-Assagba E, Futakuchi K, Wopereis MC (2013) Estimation of cultivated area, number of farming households and yield for major rice-growing environments in Africa. In: Wopereis MCS, Johnson DE, Ahmadi N, Tollens E, Jalloh A (eds) Realizing Africa's rice promise, 35-45. http://africarice.org/publications/rice promise/Chap3\%209781845938123.pdf. Accessed 12 December 2019

Dunkelman A, Kerr M, Swatuk LA (2018) The new green revolution: enhancing rainfed agriculture for food and nutrition security in eastern Africa. In: Water, energy, food and people across the global south. Palgrave Macmillan, Cham, p. 305-324. https://www. researchgate.net/profile/Luis_Paulo_Da_Silva/publication/ 320453943_La_Plata_River_Basin_The_Production_of_Scale_in South_American_Hydropolitics/links/5b61bf2da6fdccf0b $205 \mathrm{a} 28 \overline{2}$ La-Plata-River-Basin-The-Production-of-Scale-in-SouthAmerican-Hydropolitics.pdf\#page=323. Accessed 12 December 2019

ECI (Ebony Consulting International) (2003) Rice sub-sector study. Development Alternatives Inc.-Private Enterprise Support
Activities Project. Tanzania. http://www.value-chains.org/dyn/bds/ docs/410/DAI\%20pesa\%20Rice\%20Subsector\%20Study\% 20April\%202003.pdf. Accessed 12 December 2019

Eskola E (2005) Agricultural marketing and supply chain management in Tanzania: a case study. ESRF study on globalization and East Africa economies. Working Paper Series No. 16, University of Sussex, UK. h t t p s : / / pdfs.semantics cholar.org/b 8 f $4 /$ d07c11d6adde5897e626c7abeba55f54285a.pdf? ga=2.99425374. 1994633016.1576108803-344164896.1570751047. Accessed 12 December 2019

FAO (2019) FAOSTAT. http://faostat3.fao.org/faostat-gateway/go/to/ home/E. Accessed 18 March 2019

FEWS NET (the Famine Early Warning Systems Network) (2009) Production and market flow maps: Tanzania normal season rice. http://www.fews.net/sites/default/files/documents/reports/tz fullmap_rice_norm.pdf. Accessed 14 June 2019

Fiamohe R, Ndindeng S, Mujawamariya G, Sanyang S, Futakuchi K (2016) Responding to consumers' preference in African rice markets: experiences of Africa Rice Center. 10.22004/ag.econ.249322

Hashim I, Mamiro DP, Mabagala RB, Tefera T (2018) Smallholder farmers' knowledge, perception and management of rice blast disease in upland rice production in Tanzania. J Agr Sci 10(7):137145. https://doi.org/10.5539/jas.v10n7p137

Ikegami K (1995) A study on technology transfer of paddy cultivation in the Kilimanjaro region, Tanzania. Mem Fac Agr Kinki Univ 28:65$75 \mathrm{https} / / /$ kindai.repo.nii.ac.jp/?action=repository_uri\&item_id= 4912\&file_id=40\&file_no=1. Accessed 12 December 2019

Ikegami K (2001) Changes in food production by irrigated paddy cultivation in the Kilimanjaro region. Mem Fac Agr Kinki Univ 34:55$70 \mathrm{https} / / /$ kindai.repo.nii.ac.jp/?action=repository_uri\&item_id= $4847 \&$ file_id=40\&file_no=1. Accessed 12 December 2019

Kadigi RM, Kashaigili JJ, M̄doe NS (2004) The economics of irrigated paddy in Usangu Basin in Tanzania: water utilization, productivity, income and livelihood implications. Phys Chem Earth PT A/B/C 29(15):1091-1100. https://doi.org/10.1016/j.pce.2004.08.010

Kadigi RM, Mdoe NS, Ashimogo GC, Morardet S (2008) Water for irrigation or hydropower generation? Complex questions regarding water allocation in Tanzania. Agr Water Manage 95(8):984-992. https://doi.org/10.1016/j.agwat.2008.03.008

Kafiriti EM, Dondeyne S, Msomba S, Deckers JA, Raes D (2003a) Variations in agronomic characteristics of irrigated rice varieties: lessons from participatory trials in south eastern Tanzania. Food Agric Environ 1:273-277 https://lirias.kuleuven.be/retrieve/ 185866. Accessed 12 December 2019

Kafiriti EM, Dondeyne S, Msomba S, Deckers J, Raes D (2003b) Coming to grips with farmers' variety selection: the case of new improved rice varieties under irrigation in south east Tanzania. Tropicultura 21(4):211-217 http://www.tropicultura.org/text/ v21n4/211.pdf. Accessed 12 December 2019

Kafiriti EM, Dondeyne S, Deckers J, Raes D (2003c) Potentials for wetland rice of the coastal valleys of south eastern Tanzania: incorporating farmers' knowledge in land evaluation. The Land 7(1):41-56 https://irias.kuleuven.be/retrieve/185862. Accessed 12 December 2019

Kangalawe RY, Liwenga ET (2005) Livelihoods in the wetlands of Kilombero Valley in Tanzania: opportunities and challenges to integrated water resource management. Physics and Chemistry of the Earth, Parts A/B/C 30(11-16):968-975. https://doi.org/10.1016/j. pce.2005.08.044

Kangile RJ, Gebeyehu S, Mollel H (2018) Improved rice seed use and drivers of source choice for rice farmers in Tanzania. J Crop Improvement 32(5):622-634. https://doi.org/10.1080/15427528. 2018.1483457

Kanyeka ZL (2009) Pathogenecity of two strains of rice yellow mottle virus on aromatic rice cultivars. Tanzania J Sci 32(1):53-59. https:// doi.org/10.4314/tjs.v32i1.18429 
Kanyeka ZL, Kibanda JM, Msomba SW, Tusekelege H (2004) TXD85 and line 88: new high-yielding varieties with acceptable grain quality in Tanzania. International Rice Research Notes 29 (1): 29-30. https:/www.scribd.com/document/66911611/International-RiceResearch-Notes-Vol-29-No-1 accessed 12 December 2019

Kanyeka ZL, Kibanda JM, Msomba SC, Tusekelege H (2005) SARO 5: an emerging high yielding and profitable rice cultivar in Tanzania. Tanzania Agricultural Research \& Training Newsletter 20:14-18

Kato F (2007) Development of a major rice cultivation area in the Kilombero Valley, Tanzania. African Study Monographs Supplementary Issue 36:3-18 http://hdl.handle.net/2433/68498

Komakech HC, Van Der Zaag P, Van Koppen B (2012) The dynamics between water asymmetry, inequality and heterogeneity sustaining canal institutions in the Makanya catchment, Tanzania. Water Policy 14(5):800-820. https://doi.org/10.2166/wp.2012.196

Lazaro E, Sam AG, Thompson SR (2017) Rice demand in Tanzania: an empirical analysis. Agric Econ 48(2):187-196. https://doi.org/10. 1111/agec. 12325

Lu JJ, Chang TT (1980) Rice in its temporal and spatial perspectives. In: Luh BS (ed) Rice: production and utilization. AVI Publishing, Westport, pp 1-74

Luzi-Kihupi A, Shao-Mwalyego F, Zakayo JA, Mkuya M (2008) Mwangaza-a new early maturing, RYMV resistant rice mutant released in the United Republic of Tanzania. Plant Mutation Rep 2(1): 13-5. https://www.researchgate.net/profile/Ashura_Luzi-kihupi/ publication/242406807 Mwangaza - A New Early Maturing RYMV_Resistant_Rice_Mutant_Released_in_the_United_ Republic_of Tanzania/links/56d0435808ae85c8234825f8/ Mwangaza-A-New-Early-Maturing-RYMV-Resistant-RiceMutant-Released-in-the-United-Republic-of-Tanzania.pdf. Accessed 12 December 2019

MAFC (Ministry of Agriculture Food Security and Cooperatives) 2009 National Rice Development Strategy. https:/riceforafrica.net/ downloads/NRDS/tanzania_en.pdf. Accessed 12 December 2019

Manero A, Wheeler SA, Zuo A, Mdemu M (2019) Exploring the head versus tail-end dichotomy on yield and farm incomes in smallholder irrigation schemes in Tanzania. Water Resour Res 55(5):4322-4342. https://doi.org/10.1029/2018WR023483

Mato RRAM (2002) Groundwater pollution in urban Dar es Salaam, Tanzania: assessing vulnerability and protection priorities. Technische Universiteit Eindhoven, Eindhoven. https://doi.org/10. 6100/IR554794

Mdemu MV, Magayane MD, Lankford B, Hatibu N, Kadigi RM (2004) Conjoining rainfall and irrigation seasonality to enhance productivity of water in rice irrigated farms in the Upper Ruaha River Basin, Tanzania. Phys Chem Earth PT A/B/C 29(15):1119-1124. https:// doi.org/10.1016/j.pce.2004.08.005

Meertens HCC (1999) Rice cultivation in the farming systems of Sukumaland, Tanzania: a quest for sustainable production under structural adjustment programmes. $\mathrm{PhD}$ dissertation, Wageningen University. https://library.wur.nl/WebQuery/wurpubs/fulltext/ 136410. Accessed 12 December 2019

Meertens HCC (2003) The prospects for integrated nutrient management for sustainable rainfed lowland rice production in Sukumaland, Tanzania. Nutr Cycl Agroecosyst 65(2):163-171. https://doi.org/ 10.1023/A:1022103913683

Meertens HCC, Ndege LJ, Lupeja PM (1999) The cultivation of rainfed, lowland rice in Sukumaland, Tanzania. Agric Ecosyst Environ 76(1):31-45. https://doi.org/10.1016/S0167-8809(99)00073-0

Meertens HCC, Kajiru GJ, Ndege LJ, Enserink HJ, Brouwer J (2003) Evaluation of on-farm soil fertility research in the rainfed lowland rice fields of Sukumaland, Tanzania. Exp Agr 39(1):65-79. https:// doi.org/10.1017/S0014479702001060

Mghase JJ, Shiwachi H, Nakasone K, Takahashi H (2010) Agronomic and socio-economic constraints to high yield of upland rice in Tanzania. Afr J Agr Res 5(2): 150-158. https://www.researchgate.
net/profile/Hironobu_Shiwachi/publication/228670211_ Agronomic_and_socio-economic_constraints to high yield of upland_rice in Tanzania/links/0046353697 d88 a8167000000/ Agronomic-and-socio-economic-constraints-to-high-yield-ofupland-rice-in-Tanzania.pdf. Accessed 12 December 2019

Minot N (2010) Staple food prices in Tanzania. Paper prepared for the COMESA policy seminar (variation in staple food prices: causes, consequence, and policy options) Maputo, Mozambique. https:// www.researchgate.net/publication/46470987_Staple_food_prices in Tanzania. Accessed 12 December 2019

Mishili FJ, Temu A, Fulton J, Lowenberg-DeBoer J (2011) Consumer preferences as drivers of the common bean trade in Tanzania: a marketing perspective. J Int Food Agribus Marketing 23(2):110 127. https://doi.org/10.1080/08974438.2011.558761

Mogga M, Sibiya J, Shimelis H, Lamo J, Yao N (2018) Diversity analysis and genome-wide association studies of grain shape and eating quality traits in rice (Oryza sativa L.) using DArT markers. PLoS One 13(6):e0198012. https://doi.org/10.1371/journal.pone.0198012

Msomba SW, Kibanda JM, Penza H, Tusekelege H, Mkuya M, Kafiriti E, Mbapila JC, Kanyeka Z (2004) TXD306: a high-yielding and medium-maturing aromatic rice for the rainfed lowland and irrigated ecosystems in Tanzania. Int Rice Res Notes 29(1):30-31 https:// www.scribd.com/document/66911611/International-RiceResearch-Notes-Vol-29-No-1. Accessed 12 December 2019

Mwakalila S (2005) Water resource use in the great Ruaha Basin of Tanzania. Phys Chem Earth PT A/B/C 30(11):903-912. https://doi. org/10.1016/j.pce.2005.08.037

Mwaseba DL (2005) Impact of agricultural research: a study of on-farm development effects of agricultural research in southern highlands and eastern zones of Tanzania. PhD dissertation, Norwegian University of Life Sciences. http://hdl.handle.net/11250/2574520

Mwaseba DL, Kaarhus R, Johnsen FH, Mvena ZSK, Mattee AZ (2006) Beyond adoption/rejection of agricultural innovations: empirical evidence from smallholder rice farmers in Tanzania. Outlook Agr 35(4):263-272. https://doi.org/10.5367/000000006779398245

Mwaseba DL, Kaarhus R, Johnsen FH, Mattee AZ, Mvena ZS (2007) Rice for food and income: assessing the impact of rice research on food security in the Kyela and Kilombero districts of Tanzania. Outlook Agr 36(4):231-236. https://doi.org/10.5367/ 000000007783418534

Nakano Y, Kajisa K (2013) The determinants of technology adoption: the case of the rice sector in Tanzania. JICA-RI Working Paper 58:1-32 https://www.jica.go.jp/jica-ri/publication/workingpaper/ jrft3q00000024st-att/JICA-RI WP No58 2013.pdf. Accessed 12 December 2019

Nakano Y, Kajisa K (2014) To what extent does the adoption of modern variety increase productivity and income? A case study of the rice sector in Tanzania. JICA-RI Working Paper 71:1-28 https://www. jica.go.jp/jica-ri/ja/publication/workingpaper/jrft3q0000000x6i-att/ jica-ri wp no.71 2014.pdf. Accessed 12 December 2019

Nakano Y, Tsusaka TW, Aida T, Pede VO (2018) Is farmer-to-farmer extension effective? The impact of training on technology adoption and rice farming productivity in Tanzania. World Dev 105:336-351. https://doi.org/10.1016/j.worlddev.2017.12.013

Nhamo N, Rodenburg J, Zenna N, Makombe G, Luzi-Kihupi A (2014) Narrowing the rice yield gap in East and Southern Africa: using and adapting existing technologies. Agric Syst 131:45-55. https://doi. org/10.1016/j.agsy.2014.08.003

Nkonya N, Barreiro-Hurle J (2012) Analysis of incentives and disincentives for rice in the United Republic of Tanzania. Technical notes series, MAFAP, FAO, Rome. http://repository.businessinsightz.org/ bitstream/handle/20.500.12018/7225/ANALYSIS\%20OF\% 20INCENTIVES\%20AND\%20DISINCENTIVES\%20FOR\% $20 \mathrm{CASHEW} \% 20$ NUTS $\% 20$ IN $\% 20$ THE $\% 20$ UNITED $\%$ 20REPUBLIC $\% 200 F \% 20$ TANZANIA.pdf? sequence=1. Accessed 12 December 2019 
Nkuba J, Ndunguru A, Madulu R, Lwezaura D, Kajiru G, Babu A, Chalamila B, Ley G (2016) Rice value chain analysis in Tanzania: identification of constraints, opportunities and upgrading strategies. Afr Crop Sci J 24(1):73-87. https://doi.org/10.4314/acsj.v24i1.8S

Nzomoi J, Anderson I (2013) The rice market in East Africa. The 4th International Conference of the African Association of Agricultural Economists. Hammamet, Tunisia. pp1-46. https://ageconsearch. umn.edu/record/161272/files/JOSEPH\%20NZOMOI\%20\%20_\% 20IAN\%20ANDERSON.pdf. Accessed 12 December 2019

Rajabu KR (2007) Use and impacts of the river basin game in implementing integrated water resources management in Mkoji sub-catchment in Tanzania. Agr Water Manage 94(1):63-72. https://doi.org/10.1016/j.agwat.2007.08.010

Rodenburg J. (2013) Inland valleys: Africa's future food baskets. In: Wopereis MCS, Johnson DE, Ahmadi N, Tollens E, Jalloh A (eds) Realizing Africa's rice promise, 276-293. http://www.africarice.org/ publications/rice_promise/Chap22\%209781845938123.pdf. Accessed 12 December 2019

Rodenburg J, Riches CR, Kayeke JM (2010) Addressing current and future problems of parasitic weeds in rice. Crop Prot 29(3):210 221. https://doi.org/10.1016/j.cropro.2009.10.015

Rodenburg J, Zwart SJ, Kiepe P, Narteh LT, Dogbe W, Wopereis MC (2014) Sustainable rice production in African inland valleys: seizing regional potentials through local approaches. Agric Syst 123:1-11. https://doi.org/10.1016/j.agsy.2013.09.004

Rodenburg J, Cissoko M, Kayeke J, Dieng I, Khan ZR, Midega CA, Onyuka EA, Scholes JD (2015) Do NERICA rice cultivars express resistance to Striga hermonthica (Del.) Benth. and Striga asiatica (L.) Kuntze under field conditions? Field Crop Res 170:83-94. https://doi.org/10.1016/j.fcr.2014.10.010

Rodenburg J, Cissoko M, Dieng I, Kayeke J, Bastiaans L (2016) Rice yields under Rhamphicarpa fistulosa-infested field conditions, and variety selection criteria for resistance and tolerance. Field Crop Res 194:21-30. https://doi.org/10.1016/j.fcr.2016.04.030

Satoh H, Ching'ang'a HM, Ilaila D, Katayama TC (1990) On distribution and grain morphology of cultivated rice collected in Tanzania, 1988. Kagoshima University Research Center for the South Pacific, Occasional Papers, 18: 73-82. https://core.ac.uk/download/pdf/ 144569328.pdf. Accessed 12 December 2019

Schut M, Rodenburg J, Klerkx L, Kayeke J, van Ast A, Bastiaans L (2015) RAAIS: Rapid Appraisal of Agricultural Innovation Systems (Part II). Integrated analysis of parasitic weed problems in rice in Tanzania. Agr Syst 132:12-24. https://doi.org/10.1016/j. agsy.2014.09.004

Sekiya N, Khatib KJ, Makame SM, Tomitaka M, Oizumi N, Araki H (2013) Performance of a number of NERICA cultivars in Zanzibar, Tanzania: yield, yield components and grain quality. Plant Prod Sci 16(2):141-153. https://doi.org/10.1626/pps.16.141

Sekiya N, Tomitaka M, Oizumi N, Assenga A, Jacob MK (2015) Farmerto-farmer extension facilitated by agricultural training institutions: a case of NERICA dissemination in Tanzania. Plant Prod Sci 18(3): 398-406. https://doi.org/10.1626/pps. 18.398
Sekiya N, Tomitaka M, Oizumi N, Pyuza AG, Shayo RJ, Assenga AN, Iemoto T, Ishido K, Saiki Y, Tamura K, Nakamura T (2017) Importance of basic cultivation techniques to increase irrigated rice yields in Tanzania. Paddy Water Environ 15(4):847-859. https://doi. org/10.1007/s10333-017-0597-8

Senda M (1999) Rice marketing system in Tanzania. MissPub Chugoku Natl Agric Exp Stn 32:1-83

Senthilkumar K, Tesha BJ, Mghase J, Rodenburg J (2018) Increasing paddy yields and improving farm management: results from participatory experiments with good agricultural practices (GAP) in Tanzania. Paddy Water Environ 16(4):749-766. https://doi.org/10. 1007/s10333-018-0666-7

Singh RK, Muror R, Ndayiragije A, Bigirimana J, Kimani JM, Kanyeka ZL, Surapong S, Singh YP, Ndikumana I, Lamo J, Mkuya MS, Tusekelege H, Rickman J (2013) Rice breeding activities in Eastern and Southern Africa. SABRAO J Breed Genet 45(1):73$83 \mathrm{http}: / /$ content.ebscohost.com/ContentServer.asp?T=P\&P=AN\& $\mathrm{K}=113208240 \& \mathrm{~S}=\mathrm{R} \& \mathrm{D}=\mathrm{a} 9 \mathrm{~h} \& \mathrm{Ebs}$ c o Content $=$ dGJyMNXb4kSep684wtvhOLCmr1GeqK5Ssqu4TLCWxWXS \&ContentCustomer=dGJyMPGnsEmyrbVOuePfgeyx 44Dt6fIA. Accessed 12 December 2019

Suvi WT Shimelis H, Laing M, Mathew I, Shayanowako AIT (2019) Assessment of the genetic diversity and population structure of rice genotypes using SSR markers. Acta Agr Scand B-S P 1-11. https:// doi.org/10.1080/09064710.2019.1670859

Therkildsen O (2011) Policy making and implementation in agriculture: Tanzania's push for irrigated rice. DIIS Working Paper 2011:26, Danish Institute for International Studies, Copenhagen. https:// www.econstor.eu/bitstream/10419/122235/1/675425638.pdf. Accessed 12 December 2019

Tippe DE, Rodenburg J, van Ast A, Anten NPR, Dieng I, Kayeke J, Cissoko M, Bastiaans L (2017) Delayed or early sowing: timing as parasitic weed control strategy in rice is species and ecosystem dependent. Field Crop Res 214:14-24. https://doi.org/10.1016/j.fcr. 2017.08.013

USDA (United States of America Department of Agriculture) 2019 United States Department of Agriculture, Foreign Agricultural Service. http://www.fas.usda.gov/psdonline/. Accessed 18 March 2019

Walshaw SC (2010) Converting to rice: urbanization, Islamization and crops on Pemba Island, Tanzania, AD 700-1500. World Arch 42(1): 137-154. https://doi.org/10.1080/00438240903430399

Wilson RT, Lewis I (2015) The rice value chain in Tanzania. A report from the Southern Highlands Food Systems Programme, FAO, 9. http://www.ipcinfo.org/fileadmin/user_upload/ivc/PDF/SFVC/ Tanzania_rice.pdf. Accessed 12 December 2019

Yamada R (1999) The development of irrigated rice farming in Tanzania and associated socio-economic considerations. J Rural Plann Assoc 18(2):126-137. https://doi.org/10.2750/arp.18.126

Publisher's note Springer Nature remains neutral with regard to jurisdictional claims in published maps and institutional affiliations. 